\title{
Kajian Heat Shock Protein 90 (HSP90) dalam Pencarian Kandidat Penghambatnya melalui Ekplorasi Bahan Alam Indonesia
}

\author{
(Review On Heat Shock Protein 90 (HSP90) for Exploration of Its Inhibitor Candidates \\ through Indonesian Natural Resources)
}

\author{
Rehmadanta Sitepu* \\ Program Studi S1 Farmasi, Fakultas Sains dan Teknologi, Universitas Ma Chung, Malang, Indonesia, 95151
}

\section{Article Info:}

Received: 22 February 2019

in revised form: 25 February 2019

Accepted: 12 March 2019

Available Online: 14 March 2019

\section{Keywords:}

HSP90

HSP90 inhibitor

Anticancer candidate

Corresponding Author:

Rehmadanta Sitepu

Program Studi S1 Farmasi,

Fakultas Sains dan Teknologi,

Universitas Ma Chung

Malang, 95151, Jawa Timur,

Indonesia

Email:

rehmadanta.sitepu@machung.ac.id

\begin{abstract}
Exploration on anticancer candidates on inhibition of Heat Shock Protein (HSP) activity are increasing in the past ten years. Some of HSP90 inhibitor candidates were in third phase of clinical trials. However, this issue is not followed by the emergency of HSP90 inhibitor research in Indonesia, not only study on natural source but also on synthetic candidates. This study aims to look the development of tracking HSP90 inhibitor candidates globally so that it can initiate the related research in Indonesia. Study of HSP90 and its inhibitors were taken from scientific articles in the range from 2009 to 2018. HSP90 and its inhibitors have important values in the dynamics of functions and stability of proteins to maintain survival of cells. This also include the oncogene proteins that involve in cell proliferation such as tyrosine kinases, transcription factors, and regulatory proteins that expression and interaction depend on HSP90. Expression of the transcription factor p53, Alk gene, Wnt gene, glucocorticoid receptors have also links with HSP90 protein activity. Some candidates for inhibitor of HSP90 have been entering clinical trials such as geldanamycin analogues, resorcinol derivatives, and purines analog. Candidates from natural sources that are also being developed such as luteolin, licochalcone A, oleochantal, novobiocin, epigallocathecin gallat, silybin, deguelin, and celastrol from terpenoid class, Apigenin from flavon class, Curcumin, and Gambogat Acid. HSP90 inhibitors which are entering the third phase of clinical trial are ganetespib from the resorcinol derivative and retaspimycin from geldanamisin analog group. Exploration of HSP90 inhibitors from Indonesia natural resources still have great potential to be developed because they have high impact values as anticancer candidates.
\end{abstract}

Copyright $(2017$ JFG-UNTAD

This open access article is distributed under a Creative Commons Attribution (CC-BY-NC-SA) 4.0 International license.

How to cite (APA 6th Style):

Sitepu., R. (2019). Kajian Heat Shock Protein 90 (HSP90) dalam Pencarian Kandidat Penghambatnya melalui Ekplorasi Bahan Alam Indonesia. Jurnal Farmasi Galenika : Galenika Journal of Pharmacy, 5(1), 1-11. doi:10.22487/j24428744.2019.v5.i1.12012 


\begin{abstract}
ABSTRAK
Pencarian kandidat antikanker yang bertujuan untuk memberikan penghambatan pada Heat Shock Protein (HSP) 90 berkembang cukup berarti dalam satu dekade belakangan ini. Beberapa penghambat HSP90 yang ditemukan sudah berada pada tahap uji klinis fase tiga. Namun, perkembangan ini tidak diikuti dengan munculnya penelitian penghambat HSP90 di Indonesia, baik dari pencarian kandidat yang dibuat secara sintetik maupun yang ditemukan dari bahan alam asli Indonesia. Kajian ini bertujuan untuk melihat secara umum mengenai perkembangan penelusuran kandidat penghambat HSP90 secara global sehingga dapat menginisiasi penelitian sejenis di Indonesia. Kajian artikel HSP serta penghambatan HSP diambil dari artikel ilmiah mulai dari tahun 2009 hingga 2018 mengingat dalam rentang tahun tersebut jumlah publikasi terkait dengan penghambatan HSP90 meningkat secara signifikan. HSP90 dan penghambatnya memiliki nilai penting dalam dinamika stabilitas dan fungsi protein untuk menjaga keberlangsungan hidup suatu sel. Ini juga mencakup protein-protein onkogen yang terlibat dalam regulasi pembelahan sel seperti protein tirosin kinase, faktor transkripsi, dan protein-protein regulator yang ekspresi dan aktivitasnya bergantung pada HSP90. Ekspresi faktor transkripsi p53, gen Alk, gen Wnt, reseptor glukokortikoid juga memiliki kaitan dengan aktivitas HSP90. Beberapa kandidat penghambat HSP90 yang telah memasuki uji klinis seperti turunan Resorsinol, analog Purin, dan Geldanamisin. Kandidat dari bahan alam yang sedang dikembangkan seperti Luteolin, Licochalcone A, Oleochantal, Novobiocin, Epigallokatekin Galat, Silybin, Deguelin, dan Celastrol dari golongan terpenoid, Apigenin dari golongan flavon, Kurkumin, dan Asam Gambogat. Kandidat inhibitor HSP90 yang memasuki fase 3 uji klinis yaitu retaspimycin dari golongan analog geldanamisin dan ganetespib dari turunan resorsinol. Kandidat inhibitor HSP90 hasil eksplorasi bahan alam Indonesia memiliki potensi besar untuk dikembangkan karena memiliki nilai dampak yang tinggi sebagai kandidat antikanker.
\end{abstract}

Kata Kunci : Penghambat HSP90, HSP90, Antikanker

\section{PENDAHULUAN}

Heat Shock Protein (HSP) pada awalnya diketahui sebagai protein yang akan terinduksi atau terekspresi ketika sel terekspos dengan temperatur di atas temperatur normal untuk pertumbuhannya (Ludewig \& Flor, 2013). Semula ekspresi protein ini terinduksi pada kelenjar saliva lalat buah (Drosophilia) yang diamati pada saat diberikannya kejutan temperaturnya. Namun, beberapa tahun terakhir diketahui bahwa HSP tidak hanya terlibat dalam kejutan temperature saja, melainkan hal-hal yang menyebabkan sel mendapatkan stres metaboli seperti: anoksi, iskemia, ion-ion logam berat, etanol, nikotin, bahkan agen-agen virus (Whitley, Goldberg, \& Jordan, 1999).

HSP termasuk ke dalam golongan protein chaperone yang bertanggung jawab dalam memperbaiki kembali lipatan protein yang semula rusak akibat stress metabolik, perakitan kompleks protein, penghantaran protein ke lokasi subseluler yang tepat, kontrol siklus sel, dan proteksi sel terhadap apoptosis. Ada dua tipe utama protein ini yang digolongkan berdasarkan

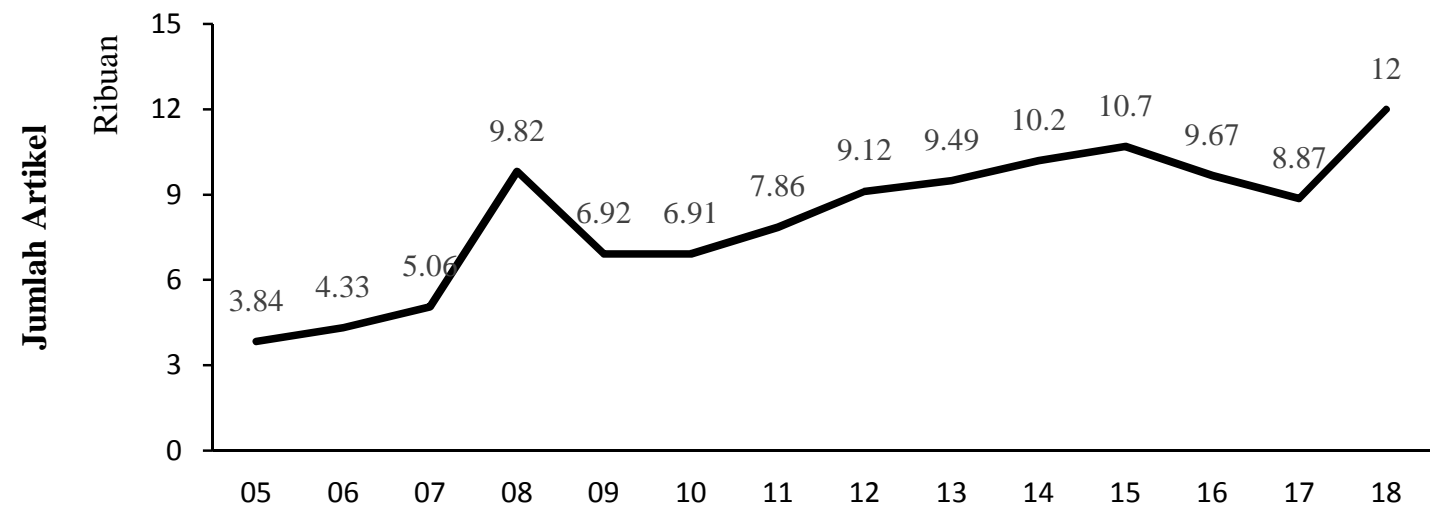

Tahun Publikasi (2005-2018)

Gambar 1. Jumlah artikel ilmiah terkait inhibitor HSP90 dalam 13 tahun terakhir yang bersumber dari Google Scholar 
pelipatan protein (protein folding). Tipe pertama ialah HSP27, HSp70, dan HSP90 yang berinteraksi langsung dengan permukaan protein yang belum dilipat/folding. Tipe yang kedua adalah HSP60 yang membentuk suatu kompleks yang dinamakan resembling folding chamber, dimana dapat mengembalikan kembali konformasi aktif suatu protein (Calderwood \& Gong, 2016).

Dalam beberapa tahun belakangan ini, penelitian terkait HSP telah banyak mengalami perkembangan yang sangat signifikan. HSP memegang peranan dalam terjadinya suatu penyakit. Perannya dalam proliferasi, diferensiasi, dan kasinogenesis sel menyebabkan banyak penelitian yang dilakukan untuk terkait dengan molekuler kanker dan metastasis (Wu et al., 2017) bahkan pengembangan obat yang mentargetkan protein ini telah dilakukan dan sekarang sudah masuk ke dalam uji klinis (da Silva \& Ramos, 2012). HSP juga diketahui memegang peranan penting dalam mengaktivasi respon adaptif (Javid, MacAry, \& Lehner, 2014), berperan dalam penyakit neurodegenaratif (Bakthisaran, Tangirala, \& Rao, 2015), dan sinyalisasi reseptor Glut dalam resistensi insulin (Wijaya, Santosa, \& Waspadji, 2009).

Pada tinjauan ini lebih difokuskan kepada peranan HSP90 dalam mekanismenya sebagai pencetus kanker dan inhibitor HSP90 yang telah banyak mengalami perkembangan untuk digunakan sebagai terapi penyakit kanker.

Dari hasil penelusuran menggunakan Google Scholar, seperti terlihat pada Gambar 1, jumlah artikel ilmiah yang terkait dengan inhibitor HSP90 meningkat secara signifikan dari tahun 2008 hingga tahun 2018. Pada tahun 2005 tercatat hanya sekitar 3840 publikasi. Pada tahun 2007 jumlah publikasinya meningkat hingga 5060 artikel ilmiah. Peningkatan yang paling signifikan terjadi pada tahun 2008 dimana dimana jumlah publikasi berada pada 9820 artikel ilmiah. Jumlah publikasi ini terus meningkat pada tahun 2012 hingga 2018 dimana rata-rata jumlah publikasi mencapai 10000an artikel ilmiah. Oleh karena itu, maka rentang pengambilan data diambil mulai dari tahun 2008-2018.

\section{APA ITU HSP90?}

HSP90 merupakan protein chaperon dengan ukuran 90 KDa. Protein ini ditemukan melimpah hampir diseluruh kompartemen sel. Protein ini berperan penting dalam pelipatan, pematangan, stabilisasi, dan aktivasi protein lainnya. Aktivitas protein in bergantung kepada ATP yang berikatan dengan protein ini (Hartson \& Matts, 2012). HSP90, seperti pada Gambar 2, adalah protein yang aktif dalam bentuk dimer. HSP90 terdiri dari 3 domain, yaitu domain terminal-N, domain tengah (Mid), dan domain terminal-C. Hal ini berbeda dengan HSP70 yang memiliki dua domain, yaitu domain terminal-N dan domain pengikatan substrat (Javid et al., 2014). Domain terminal-N terlibat dalam pengikatan nukleotida dan hirolisis, dimana terdapat kantung pengikatan ATP (Didenko et al., 2014). Domain Mid akan terhubung dengan domain terminal-N melalui

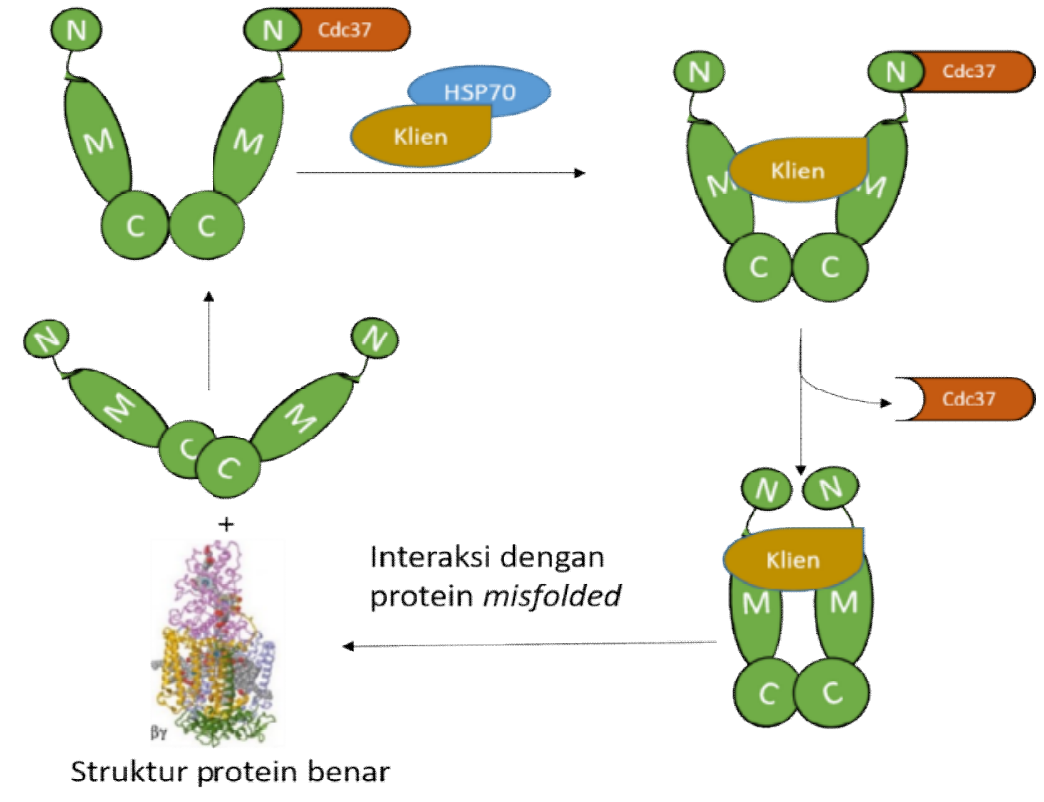

Gambar 2. Mekanisme kerja HSP90 
daerah yang tidak beraturan, yang dinamakan charge linker, yaitu penghubung yang memiliki muatan karena terdiri dari residu asam dan basa (Mayer \& Le Breton, 2015). Domain ini berperan penting dalam hidrolisis ATP dan berkontribusi dalam pengikatan substrat (Didenko, Duarte, Karagöz, \& Rüdiger, 2012). Domain terminal-C merupakan domain dimana terjadinya dimerisasi homolog protein ini (Didenko et al., 2012). Domain ini juga berkontribusi dalam pengikatan substrat. Motif konservasi MEEVD pada domain terminal-C berfungsi sebagai situs pengikatan untuk berinteraksi dengan ko-chaperon, yang memiliki ciri ada pengulangan peptide tetratiko (Tetratico Peptide Repeated/TPR) (Buchner \& Li, 2013).

Secara umum, fungsi HSP90 tidak memiliki perbedaan yang besar baik pada tanaman ataupun sel eukariotik. Pada sel mamalia, kehadiran HSP90 berada pada sitoplasma, mitokondria, dan reticulum endoplasma. Bahkan protein ini ditemukan pada permukaan sel kanker dan juga disekresikan ekstraseluler (Makhnevych \& Houry, 2012). Pada tanaman, protein ini ditemukan juga di sitoplasma, kloroplast, mitokondria, dan retikulum endoplasma (Neckers \& Trepel, 2014). Penelaahan HSP90 pada protozoa juga sangat menarik karena memiliki perbedaan struktural. Pada Giardia lamblia, diketahuia HSP90 yang ditemukan pada protozoa ini hanya memiliki domain terminal-N dan domain terminal-C (Roy, Nageshan, Ranade, \& Tatu, 2012). Pada dengan mammalia dan ragi yang memiliki dua isoform HSP90 yang ada pada sitosol, pada Zebrafish ditemukan tiga isoform dan hanya satu HSP90 homolog ditemukan pada Caenorhabditis elegans dan Drosophila melanogaster (Haslbeck, Kaiser, \&
Richter, 2012).

\section{HSP 90 BEKERJA DENGAN BANTUAN HSP70}

Dalam proses pelipatan protein, HSP70 yang pertama sekali berikatan dan memulai pelipatan pada proteinprotein yang sama sekali belum dilakukan pelipatan. HSP70 mengenali bagian hidrofobik protein. Peran HSP90 dalam pelipatan protein dimulai pada pertengahan proses pelipatan setelah HSP70 melakukan tugasnya (Karagöz \& Rüdiger, 2015). Mekanisme ini dapat dilihat pada Gambar 3 terkait dengan mekanisme kerja HSP90. HSP90 membutuhkan sejumlah kelompok besar yang dinamakan ko-chaperon dalam melakukan aktivitasnya. Interaksinya dengan protein klien mencakup protein-protein kinase, reseptor steroid, faktor transkripsi seperti p53, dan protein Tau yang mengalami gangguan (Karagöz \& Rüdiger, 2015). Ko-chaperon yang berikatan dengan HSP90 sehingga menjadi aktif yaitu p23, Sgt1, Cdc37, Aha1, Hop, PP5, FKBP51, TTC4, XAP2, dan AIPL1 (Johnson, 2012).

\section{KO-CHAPERON HSP90}

P23 difosforilasi oleh CK2 (casein kinase 2) pada ser-113 dan ser-118. Pembentukan kompleks p23CK2-HSP90 meningkatkan aktivitas prostaglandin kinase. Mutasi pada domain terminal-N dengan cara mengubah asam amino yang bisa difosforilasi menjadi tidak bisa difosforilasi akan mengurangi pengikatan HSP90 ke Aha1 dan p23 (Mollapour \& Neckers, 2012). Sti/Hop dirilis oleh HSP90 ketika berikatan dengan nukleotida dan p23 (Richter,

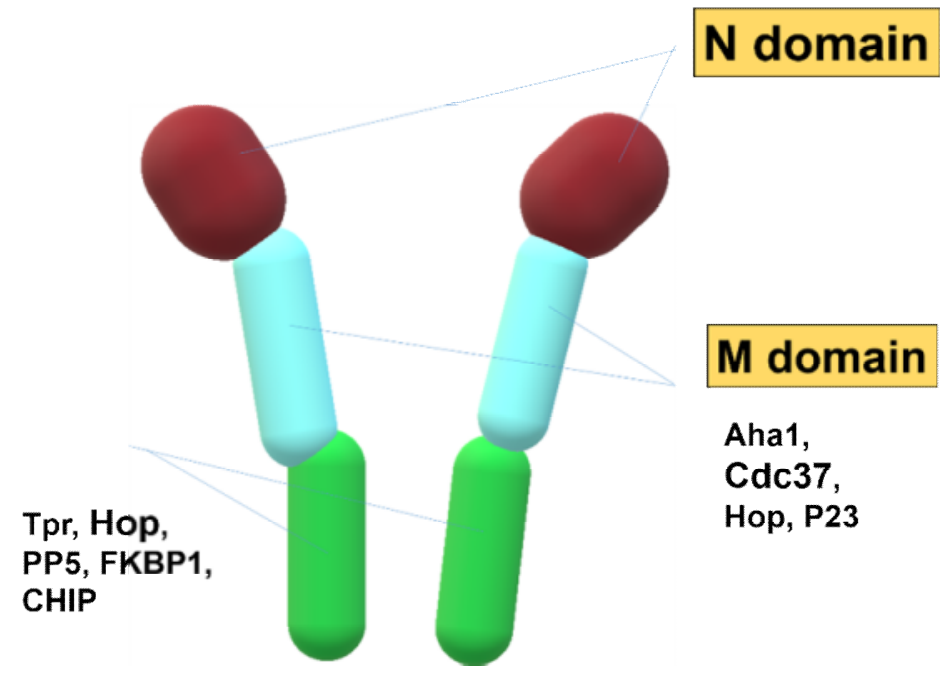

Gambar 3. Struktur HSP90 dan interaksinya dengan beberapa protein 
Haslbeck, \& Buchner, 2010). Konformasi menutup HSP90 diinduksi oleh ATP dan ko-chaperon p23 (Karagöz et al., 2014). p23 merupakan protein yang bersifat asidik/asam dan memiliki ekor tidak berstruktur pada terminal-C protein tersebut. Hal ini penting untuk mengaktifkan aktivitas intrinsik chaperon. Kompleks p23-HSP90-PPi (Peptidil Isomerase) merupakan komponen kompleks SHR/reseptor steroid yang fungsinya menstabilkan konformasi tertutup HSP90 (Buchner \& Li, 2013).

NLR (Nucleotide Leucine-rich Repeat) adalah domain protein yang dapat memicu aktivasi sistem imun. Aktivasi ini bergantung dari aktivitas HSP90 dalam mengenali NLR. Interaksi HSP90 terhadap NLR dimotori oleh Sgt1 yang akan berinteraksi antara domain CS-nya dengan domain-N HSP90. Domain CS ini strukturnya mirip dengan p23 (R. Wang et al., 2016). Ko-chaperon Rar1 juga membentuk kompleks dengan HSP90 dan Sgt1 untuk menginduksi aktivitas HSP90 terhadapa NLR. Domain terminal-C Sgt1 berikatan dengan NLR dan domain terminal-N berikatan dengan HSP90 (Siligardi, Zhang, \& Prodromou, 2018). Lebih detailnya, Sgt1 terdiri dari 3 (tiga) domain utama, yaitu: TPR (tetratri-copeptide repeats), CS
(CHORD-containing protein and SGT1) dan SGS (SGT1 specific domain); domain SGS menghubungkan SGT1 dan protein yang mengandung LRR (pengulangan leusin). Umumnya domain TPR berinteraksi dengan domain terminal-C HSP90, tetapi pada Sgt1 tidak menunjukkan adanya interaksi tersebut. Domain CS pada Sgt1 yang memediasi interaksi dengan terminal-C HSP90(Kadota \& Shirasu, 2012). Sgt1 satu juga diketahui membantu HSP90 dalam perakitan kinetokor. Penempelan kromosom pada spindel pada proses mitosis diinisasi dengan perakitan suatu kompleks kinetokor yang dinamakan Centromer Binding Complex 3 (CBF3). CBF3 terdiri dari empat komponen, yaitu: Cep3, Ctf13, Skp1, dan Ndc10. Aktivitas Ctf1 salah satunya bergantung pada HSP90 dan ko-chaperon Sgt1 (Makhnevych \& Houry, 2012). Pada pertumbuhan benih Arabidopsis thaliana, Sgt1 juga membantu dalam interaksi antara HSP90 dan TIR1, yang merupakan ko-reseptor auksin yang memicu pertumbuhan tanaman tersebut (R. Wang et al., 2016).

Cdc37 berperan membantu HSP90 dalam mengaktivasi protein-protein kinase (Siligardi et al., 2016). Protein ini berinteraksi dengan Cdk4, Akt, dan

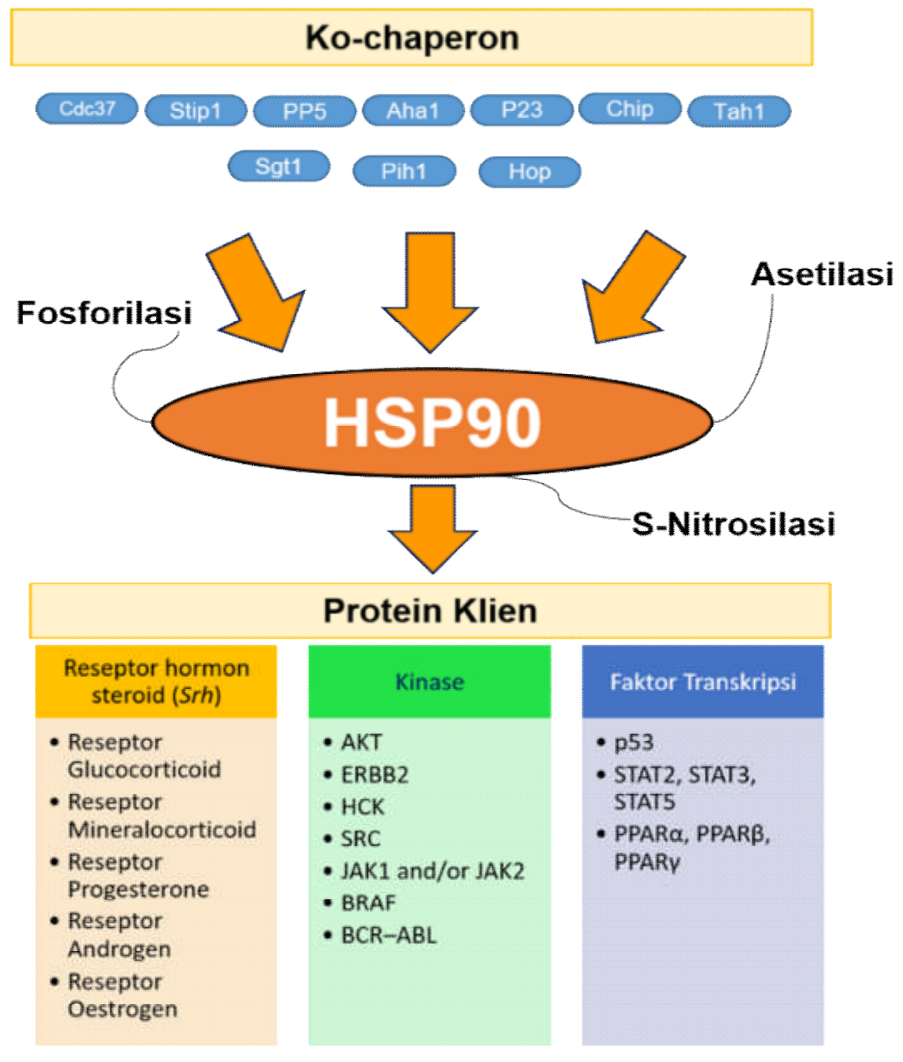

Gambar 4. Ko-chaperon HSP90 yang membantu berinteraksi dengan protein klien 
Raf (Mishra, Flynn, Starr, \& Bolon, 2016). Protein ini terdiri dari tiga bagian, yaitu: domain terminal-N yang berikatan dengan protein kinase, domain tengah (Mid) yang berinteraksi dengan HSP90, dan domain terminal-C yang belum diketahui fungsi sebenarnya. Interaksi Cdc37 dengan Cdk4 kinase diketahui untuk memastikan kinase memiliki pelipatan yang baik pada lobus N (Verba et al., 2016). Diketahui juga bahwa situs pengikatan Cdc37 saling bertindihan dengan situs pengikatan Tau, suatu protein yang terlibat dalam transportasi aksonal pada neuron, diantara HSP90-N dan HSP90-M (Karagöz et al., 2014). Interaksi Cdc37 dengan Raf dan Akt meregulasi fosforilasi yang menyebakan perubahan konformasi dan aktivasi kinase (Takai, Xie, De Lange, \& Pavletich, 2010).

p53 juga diketahui meregulasi aktivitas ATPase HSP90 melalui efek pada peningkatan aktivitas Aha1 yang merupakan protein reseptor klien aril hidrokarbon (Ahr/aryl hydrocarbon receptor) (Kochhar et al., 2014). Modulasi p53 ini memicu perubahan ekspresi gen target Wnt (Okayama et al., 2014). Ahal adalah suatu aktivator yang juga dapat merilis Hop/Sti1 dari HSP90. Aha1 juga dapat merilis Cdc37 dan nukleotida dari HSP90 (Buchner $\& \mathrm{Li}, 2013)$.

Ada sekitar 20 protein yang bertindak sebagai kochaperon yang membantu aktivitas HSP90. Beberapa ko-chaperon di atas dibahas karena memiliki kaitan dengan kanker, neurodegeneratif, dan interaksi dengan virus. Gambar 4 akan memberikan sedikit gambaran beberapa Ko-chaperon yang membantu interaksi HSP90 terhadap protein klien.

\section{Kanker}

Peningkatan aktivitas HSP90 diketahui banyak terjadi pada sel-sel kanker. Beberapa penelitian menunjukkan bahwa HSP berperan dalam pertumbuhan dan kelangsungan hidup sel kanker. HSP90 berperan penting dalam meregulasi onkogen, apoptosis, dam resistensi kemoterapi. Peningkatan aktivitas HSP90 ditemukan pada kanker payudara, kolon, dan paru-paru (Soudry et al., 2017).

Protein LIM Kinase 1 (LIMK1) adalah protein kinase serin yang meregulasi aktin sitoskeleton melalui fosforilasi dan inaktivasi faktor depolimerisasi aktin, kofilin. Aktivitas LIMK1 dan fosforilasinya meningkat pada sel kanker payudara metastasis. Hal ini disebakan karena peningkatan waktu paruh protein tersebut di dalam sel kanker yang distabilkan protein HSP90 ( $\mathrm{Li}$ et al., 2006). Aktivasi onnkogen vrsc dan reseptor glukortikoid juga diketahui bergantung pada interaksinya dengan HSP90 (Whitesell \& Lindquist, 2005). HSP90 dapat mematangkan kedua protein tersebut melalui proses hidrolisis ATP sehingga mengubah konformasi dan mengaktivasi v-rsc dan reseptor glukokortikoid (Mishra et al., 2016). Pada sel kanker paru-paru, HSP90 berperan dalam stabilisasi protein kinase seperti reseptor EFG, BRAF, HER2, dan ALK (Sang et al., 2013). Gambar 5 menunjukkan bagaimana HSP90 dapat membantu pertumbuhan sel kanker dengan beberapa cara seperti

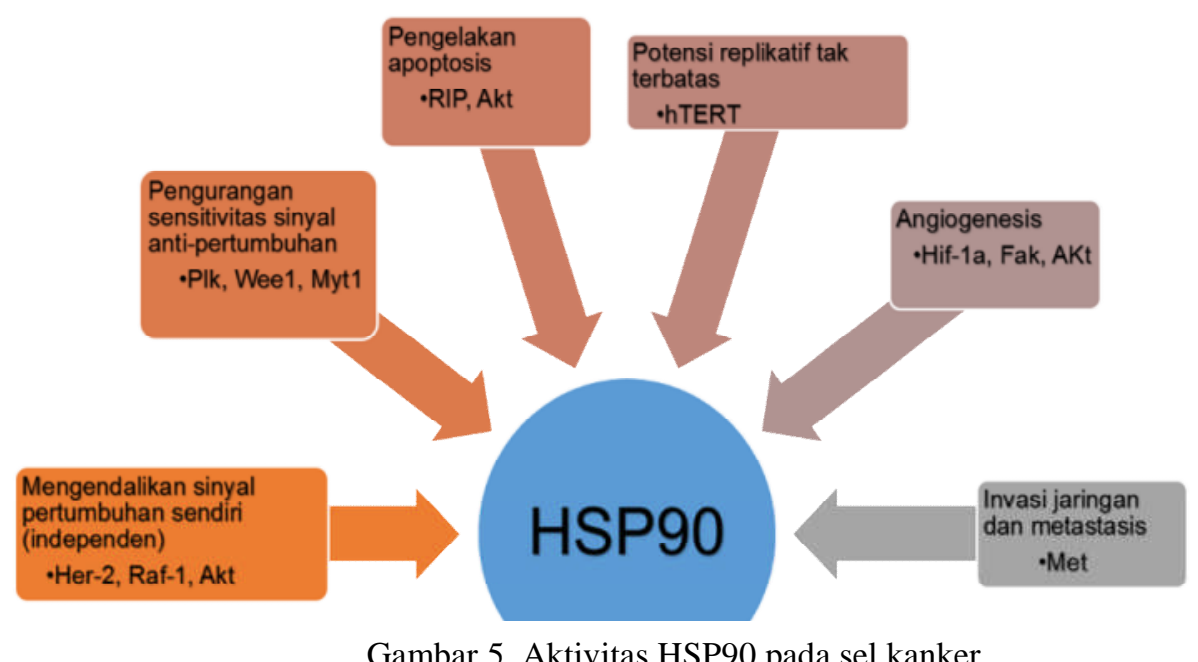

Gambar 5. Aktivitas HSP90 pada sel kanker 
Tabel 1. Daftar Kandidat Inhibitor HSP90 yang digolongkan berdasarkan mekanisme aksinya

\begin{tabular}{|c|c|c|c|c|}
\hline Mekanisme Aksi & $\begin{array}{l}\text { Golongan } \\
\text { senyawa }\end{array}$ & Nama Senyawa & Natural/Sintetik & Asal \\
\hline \multirow[t]{20}{*}{$\begin{array}{l}\text { Berikatan pada kawasan } \\
\text { pengikatan AP terminal } \\
\mathrm{N}\end{array}$} & \multirow{5}{*}{ Benzokuinon } & Geldanamycin & natural & $\begin{array}{l}\text { Streptomyces } \\
\text { hygroscopicus var. } \\
\text { geldanus }\end{array}$ \\
\hline & & Tanespimycin (17-AAG) & sintetik & \\
\hline & & Alvespimycin (17-DMAG) & sintetik & \\
\hline & & Getaspimycin (IPI-504) & sintetik & \\
\hline & & IPI-493 & sintetik & \\
\hline & \multirow{5}{*}{ Makrolida } & Radicicol & natural & $\begin{array}{l}\text { Monosporium } \\
\text { bonorden }\end{array}$ \\
\hline & & Ganetespib (STA-9090) & sintetik & \\
\hline & & NVP-AUY922 (VER52296) & sintetik & \\
\hline & & AT-13387 & sintetik & \\
\hline & & KW-2478 & sintetik & \\
\hline & \multirow{4}{*}{ Purin } & BIIB021 (CNF 2024) & sintetik & \\
\hline & & MPC-3100 & sintetik & \\
\hline & & Debio 0932 (CUDC-305) & sintetik & \\
\hline & & PU-H71 & sintetik & \\
\hline & \multirow{2}{*}{ Pirazol } & $\begin{array}{l}\text { 3,4-diaril pirazol resorsinol } \\
\text { (CCT018159) }\end{array}$ & sintetik & \\
\hline & & $\begin{array}{l}\text { isoxazole resorcinol (NVP- } \\
\text { AUY922) }\end{array}$ & sintetik & \\
\hline & Flavon & Luteolin & natural & $\begin{array}{l}\text { seledri, daun perilla, } \\
\text { teh, dan lada hijau }\end{array}$ \\
\hline & Kalkon & Licochalcone A & natural & Glycyrrhiza \\
\hline & Feniletanoid & Oleocanthal & natural & Minyak Zaitun \\
\hline & Xantonoid & Asam Gamboat & natural & Garcinia harburyi \\
\hline \multirow{4}{*}{$\begin{array}{l}\text { Berikatan ke Domain } \\
\text { terminal } \mathrm{C}\end{array}$} & Kumarin & Novobiocin & natural & Streptomyces spheroids \\
\hline & Katekin & (-)-Epigallocatechin gallate & natural & Camelia sinensis \\
\hline & Flavonolignan & Silybin & natural & Silybum marianum \\
\hline & Rotenoid & Deguelin & natural & Derris trifoliata \\
\hline \multirow{4}{*}{$\begin{array}{l}\text { Penghambat } \\
\text { pembentukan kompleks } \\
\text { HSP90/Cdc37 }\end{array}$} & Terpenoid & Celastrol & natural & Tripterygium wilfordii \\
\hline & Terpenoid & withaferin $\mathrm{A}$ & natural & Withania somnifera \\
\hline & Terpenoid & Cucurbitacin D & natural & Cucurbita texana \\
\hline & Flavon & Apigenin & natural & $\begin{array}{l}\text { Bawang, jeruk, teh, } \\
\text { kecambah }\end{array}$ \\
\hline Degradasi protein klien & Polifenol & Curcumin & natural & Curcuma longa \\
\hline
\end{tabular}

independensi dalam mengendalikan sinyal pertumbuhan, pengurangan aktivitas sinyal antipertumbuhan, pengelakan apoptosis, peningkatan replikasi yang tak terbatas, memicu angiogenesis, dan invasi ke jaringan lain. 


\section{Penghambatan aktivitas HSP90 sebagai mekanisme antikanker}

Signifikansi peranan HSP90 dalam pelipatan protein dan stabilisasinya menjadi penelaahan banyak penelitian pada tahun-tahun belakangan ini (Prince et al., 2015). Apalagi peranan HSP90 hampir mendominasi diseluruh tipe protein regulator (Hong et al., 2013). Oleh karenanya, agen penghambat aktivitas HSP90 banyak dikembangkan. Dari beberapa hasil studi, ada dua tipe strategi yang digunakan dalam mekanisme penghambatan aktivitas HSP90. Pertama, penghambatan HSP90 dapat menghambat aktivasi protein klien yang berhubungan dengan kanker seperti: reseptor tirosin-kinase (HER2 (reseptor ERB2), reseptor EGF mutan), proteinprotein yang terlibat dalam transduksi sinyal (Raf-1, BRAF mutan, dan Akt), faktor transkripsi (p53 mutan), siklus sel (Cdk4, PLK1), dan protein antiapoptosis seperti survivin. Strategi kedua adalah penghambatan HSP90 dapat menghambat aktivitas pelipatan protein yang bergantung pada HSP90, seperti Aha1, p23, Hop, dan Cdc37(Jhaveri, Taldone, Modi, \& Chiosis, 2012).

\section{Inhibitor HSP90}

Kandidat penghambat HSP90 telah banyak dikembangkan beberapa dekade belakangan ini. Berdasarkan mekanisme aksi penghambatan, inhibitor HSP90 dibedakan menjadi 4 golongan umum, yang pertama, inhibitor yang berikatan pada domain N HSP90. Inhibitor pada golongan ini umumnya mampu mengatasi aktivasi HSP90 oleh ATP. Hal ini dikarenakan pada domain $\mathrm{N}$ terdapat situs pengikatan ATP. Hampir sebagian besar kandidat inhibitor

HSP90 melakukan mekanisme aksi melalui strategi ini. Golongan senyawa penghambat aktivitas tersebut termasuk dalam golongan Benzokuinon, Makrolida, Purin, Pirazol, Flavon, Kalkon, Feniletanoid Minyak Zaitun, dan golongan Xantonoid. Beberapa kandidat tersebut sudah dikembangakan secara sintesis dan masuk ke dalam uji klinis. Secara umum, kandidat penghambat HSP90 pada domain $\mathrm{N}$ ini dikembangkan secara sintesis dari 3 golongan. Golongan pertama adalah analog Geldanamisin, yang pada awalnya digunakan sebagai antimikroorganisme. Analog Geldanamisin yang telah dikembangkan adalah Tanespimycin (17-AAG), Alvespimycin (17-DMAG), Retaspimycin (IPI-504). Analog Geldanamisin secara umum telah diuji pada kanker payudara anti HER-2, myeloma, kanker prostat, kanker ovarium, dan kanker paru-paru (Whitesell \& Lin, 2012). Golongan kedua adalah turunan Resorsinol, seperti Ganetespib (STA-9090), NVP-AUY922, AT-13387, dan KW-2478. Turunan resorsinol ini umumnya telah diuji untuk kanker rektal, melanoma, kanker paru-paru, kanker payudara HER-2, dan kanker gastrointestinal (GarciaCarbonero, Carnero, \& Paz-Ares, 2013). Golongan ketiga adalah analog purin, seperti BIIB021 (CNF 2024), MPC-3100, Debio 0932, dan PU-H71. Namun, dari golongan beberapa golongan tersebut hanya Retaspimycin dan Ganetespib yang telah memasuki uji klinik fase tiga (3).

Yang kedua adalah golongan yang berikatan pada domain terminal $\mathrm{C}$ protein HSP90. Golongangolongan senyawa yang dapat melakukan penghambatan melalui mekanisme ini adalah kumarin (Zhao, Yan, Peterson, \& Blagg, 2012), katekin (Palermo, Westlake, \& Gasiewicz, 2005; Yin, Henry, \& Gasiewicz, 2009), flavonolignan (Riebold et al., 2015), dan golongan rotenoid (Kim, Oh, Woo, Hong, \& Lee, 2009). Pengembangan senyawa sintesis pada mekanisme penghambatan ini masih sangat terbatas dan belum ada yang mengembangkan hingga pada tahapan sintesis turunnanya kecuali turunan Novobiocin dari golongan kumarin (Zhao, Moroni, Colombo, \& Blagg, 2014).

Mekanisme yang ketiga adalah penghambatan pembentukan kompleks HSP90/Cdc37. Golongan terpenoid pada umumnya yang dapat melakukan penghambatan ini seperti Celastrol (Boridy, Le, Petrecca, \& Maysinger, 2014; Klaić, Trippier, Mishra, Morimoto, \& Silverman, 2011), Withaferin A (Yu et al., 2010), dan Cucurbitasin (Hall et al., 2015). Golongan flavon seperti Apigenin juga dapat bekerja melalui mekanisme ini (He et al., 2015; Iqbal et al., 2016).

Degradasi protein klien adalah mekanisme yang belakangan ini diketahui dapat menghambat aktivitas HSP90. Umumnya penghambatan melalui mekanisme ini dilakukan oleh golongan-golongan kurkuminoid yang dapat umumnya dapat diperoleh dari alam Indonesia (Giommarelli et al., 2010; Rashmi, Santhosh Kumar, \& Karunagaran, 2003).

Kandidat inhibitor HSP90 baik secara alami maupun sintetik secara detail disajikan pada Tabel 1. Jika ditelurusi secara seksama, maka pengembangan kandidat sintetik diawali dengan penemuan kandidat penghambat HSP90 yang berasal dari alam. Kandidat penghambat HSP90 dari golongan benzokuinon seperti Geldanamycin, ditemukan pertama kali dari 
Streptomyces hygroscopicus var. geldanus yang selanjutnya dikembangkan derivatnya secara sintetik seperti 17-AAG, 17-DMAG, IPI-504, dan IPI-493. Luteoin yang terkandung di dalam seledri juga memiliki aktivitas penghambatan HSP90 dengan mekanisme aksi yang berbeda. Asam Gamboat, yang yang dapat diisolasi dari Garcinia harburyi juga memiliki aktivitas penghambat HSP90.

\section{KESIMPULAN}

Dari paparan yang disampaikan di atas, belum ada dilakukan penelahaan bahan alam Indonesia untuk penghambatan aktivitas HSP90. Dari beberapa penelusuran kajian ilmiah yang dilakukan, belum ada jurnal yang secara spesifik melakukan penelahaan tersebut. Hal ini membuka peluang besar bagi kita untuk melakukan penelahaan secara mendalam terkait kandidat dari bahan alam Indonesia terhadap penghambatan aktivitas HSP90 yang dijadikan sebagai kandidat antikanker. Sebagai contoh asam gambogat yang berasal dari Garcinia hanburyi diketahui memiliki aktivitas penghambatan HSP90(X. Wang \& Chen, 2012). Kurkumin dan Katekin juga memberikan respon penghambatan HSP90. Kita ketahui juga baik golongan Garcinia, Kurkumin, dan Katekin banyak terdapat pada tanaman-tanaman endemik asli Indonesia. Hasil ini memberikan pencerahan bagi kita bahwa penghambat HSP90 masih perlu ditelaaah terutama dari bahan alam Indonesia.

\section{DAFTAR PUSTAKA}

Bakthisaran, R., Tangirala, R., \& Rao, C. M. (2015). Small heat shock proteins: Role in cellular functions and pathology. Biochimica et Biophysica Acta - Proteins and Proteomics. https://doi.org/10.1016/j.bbapap.2014.12.019

Boridy, S., Le, P. U., Petrecca, K., \& Maysinger, D. (2014). Celastrol targets proteostasis and acts synergistically with a heat-shock protein 90 inhibitor to kill human glioblastoma cells. Cell Death and Disease, 5(5), 1-12. https://doi.org/10.1038/cddis.2014.182

Buchner, J., \& Li, J. (2013). Structure, Function and Regulation of the Hsp90 Machinery. Biomedical Journal. https://doi.org/10.4103/2319-4170.113230

Calderwood, S. K., \& Gong, J. (2016). Heat Shock Proteins Promote Cancer: It's a Protection Racket. Trends in Biochemical Sciences, 41(4), 311-323. https://doi.org/10.1016/j.tibs.2016.01.003

da Silva, V. C. H., \& Ramos, C. H. I. (2012). The network interaction of the human cytosolic $90 \mathrm{kDa}$ heat shock protein Hsp90: A target for cancer therapeutics. Journal of
Proteomics, 75(10),

https://doi.org/10.1016/j.jprot.2011.12.028

$2790-2802$.

Didenko, T., Duarte, A. M. S., Karagöz, G. E., \& Rüdiger, S. G. D. (2012). Hsp90 structure and function studied by NMR spectroscopy. Biochimica et Biophysica Acta - Molecular Cell Research. https://doi.org/10.1016/j.bbamcr.2011.11.009

Didenko, T., Veprintsev, D. B., Duarte, A. M. S., Madl, T., Radli, M., Rüdiger, S. G. D., ... Nordhues, B. A. (2014). Hsp90Tau Complex Reveals Molecular Basis for Specificity in Chaperone Action. Cell, 156(5), 963-974. https://doi.org/10.1016/j.cell.2014.01.037

Garcia-Carbonero, R., Carnero, A., \& Paz-Ares, L. (2013). Inhibition of HSP90 molecular chaperones: Moving into the clinic. The Lancet Oncology, 14(9), e358-e369. https://doi.org/10.1016/S1470-2045(13)70169-4

Giommarelli, C., Zuco, V., Favini, E., Pisano, C., Dal Piaz, F., De Tommasi, N., \& Zunino, F. (2010). The enhancement of antiproliferative and proapoptotic activity of HDAC inhibitors by curcumin is mediated by Hsp90 inhibition. Cellular and Molecular Life Sciences: CMLS. https://doi.org/10.1007/s00018-009-0233-x

Hall, J. A., Seedarala, S., Rice, N., Kopel, L., Halaweish, F., \& Blagg, B. S. J. (2015). Cucurbitacin D Is a Disruptor of the HSP90 Chaperone Machinery. Journal of Natural Products. https://doi.org/10.1021/acs.jnatprod.5b00054

Hartson, S. D., \& Matts, R. L. (2012). Approaches for defining the Hsp90-dependent proteome. Biochimica et Biophysica Acta - Molecular Cell Research. https://doi.org/10.1016/j.bbamcr.2011.08.013

Haslbeck, V., Kaiser, C. J. O., \& Richter, K. (2012). Hsp90 in non-mammalian metazoan model systems. Biochimica et Biophysica Acta - Molecular Cell Research. https://doi.org/10.1016/j.bbamcr.2011.09.004

He, J., Ning, C., Wang, Y., Ma, T., Huang, H., Ge, Y., ... Jiang, Y. (2015). Natural plant flavonoid apigenin directly disrupts Hsp90/Cdc37 complex and inhibits pancreatic cancer cell growth and migration. Journal of Functional Foods. https://doi.org/10.1016/j.jff.2015.06.052

Hong, D. S., Banerji, U., Tavana, B., George, G. C., Aaron, J., \& Kurzrock, R. (2013). Targeting the molecular chaperone heat shock protein 90 (HSP90): Lessons learned and future directions. Cancer Treatment Reviews, 39(4), 375-387. https://doi.org/10.1016/j.ctrv.2012.10.001

Iqbal, M. K., Liu, J., Nabi, F., Rehman, M. U., Zhang, H., Tahir, A. H., \& Li, J. (2016). Recovery of Chicken Growth Plate by Heat-Shock Protein 90 Inhibitors Epigallocatechin-3Gallate and Apigenin in Thiram-Induced Tibial Dyschondroplasia. Avian Diseases. https://doi.org/10.1637/11425-041816-Reg

Javid, B., MacAry, P. A., \& Lehner, P. J. (2014). Structure and Function: Heat Shock Proteins and Adaptive Immunity. The Journal of Immunology. 
https://doi.org/10.4049/jimmunol.179.4.2035

Jhaveri, K., Taldone, T., Modi, S., \& Chiosis, G. (2012). Advances in the clinical development of heat shock protein 90 (Hsp90) inhibitors in cancers. Biochimica et Biophysica Acta - Molecular Cell Research. https://doi.org/10.1016/j.bbamcr.2011.10.008

Kadota, Y., \& Shirasu, K. (2012). The HSP90 complex of plants. Biochimica et Biophysica Acta - Molecular Cell Research. https://doi.org/10.1016/j.bbamcr.2011.09.016

Karagöz, G. E., Duarte, A. M. S., Akoury, E., Ippel, H., Biernat, J., Morán Luengo, T., ... Rüdiger, S. G. D. (2014). Hsp90tau complex reveals molecular basis for specificity in chaperone action. Cell. https://doi.org/10.1016/j.cell.2014.01.037

Karagöz, G. E., \& Rüdiger, S. G. D. (2015). Hsp90 interaction with clients. Trends in Biochemical Sciences, 40(2), 117 125. https://doi.org/10.1016/j.tibs.2014.12.002

Kim, W. Y., Oh, S. H., Woo, J. K., Hong, W. K., \& Lee, H. Y. (2009). Targeting heat shock protein 90 overrides the resistance of lung cancer cells by blocking radiationinduced stabilization of hypoxia-inducible factor- $1 \alpha$. Cancer Research, 69(4), 1624-1632. https://doi.org/10.1158/0008-5472.CAN-08-0505

Klaić, L., Trippier, P. C., Mishra, R. K., Morimoto, R. I., \& Silverman, R. B. (2011). Remarkable stereospecific conjugate additions to the Hsp90 inhibitor celastrol. Journal of the American Chemical Society, 133(49), 19634-19637. https://doi.org/10.1021/ja208359a

Kochhar, A., Kopelovich, L., Sue, E., Guttenplan, J. B., Herbert, B. S., Dannenberg, A. J., \& Subbaramaiah, K. (2014). p53 modulates Hsp90 ATPase activity and regulates aryl hydrocarbon receptor signaling. Cancer Prevention Research, 7(6), 596-606. https://doi.org/10.1158/19406207.CAPR-14-0051

Li, R., Soosairajah, J., Harari, D., Citri, A., Price, J., Ng, H. L., ... Bernard, O. (2006). Hsp90 increases LIM kinase activity by promoting its homo-dimerization. The FASEB Journal. https://doi.org/10.1096/fj.05-5258fje

Ludewig, G., \& Flor, S. (2013). Harlequin Chromosomes. Brenner's Encyclopedia of Genetics: Second Edition, (February 2016), 399-401. https://doi.org/10.1016/B9780-12-374984-0.00684-7

Makhnevych, T., \& Houry, W. A. (2012). The role of Hsp90 in protein complex assembly. Biochimica et Biophysica Acta - Molecular Cell Research. https://doi.org/10.1016/j.bbamcr.2011.09.001

Mayer, M. P., \& Le Breton, L. (2015). Hsp90: Breaking the symmetry. Molecular Cell, 58(1), 8-20. https://doi.org/10.1016/j.molcel.2015.02.022

Mishra, P., Flynn, J. M., Starr, T. N., \& Bolon, D. N. A. (2016). Systematic Mutant Analyses Elucidate General and ClientSpecific Aspects of Hsp90 Function. Cell Reports, 15(3),
588-598. https://doi.org/10.1016/j.celrep.2016.03.046

Mollapour, M., \& Neckers, L. (2012). Post-translational modifications of $\mathrm{Hsp} 90$ and their contributions to chaperone regulation. Biochimica et Biophysica Acta Molecular Cell Research. https://doi.org/10.1016/j.bbamcr.2011.07.018

Neckers, L., \& Trepel, J. B. (2014). Stressing the development of small molecules targeting HSP90. Clinical Cancer Research, 20(2), 275-277. https://doi.org/10.1158/10780432.CCR-13-2571

Okayama, S., Kopelovich, L., Balmus, G., Weiss, R. S., Herbert, B. S., Dannenberg, A. J., \& Subbaramaiah, K. (2014). P53 protein regulates Hsp90 atpase activity and thereby wnt signaling by modulating Aha1 expression. Journal of Biological https://doi.org/10.1074/jbc.M113.532523

Palermo, C. M., Westlake, C. A., \& Gasiewicz, T. A. (2005). <Biochemistry 2005 PalermoEpigallocatechin gallate inhibits aryl hydrocarbon.pdf>, 5041-5052.

Prince, T., Schwartz, H., Mishra, A., Beebe, K., Scroggins, B., Zuehlke, A., ... Neckers, L. (2015). Combined HSP90 and kinase inhibitor therapy: Insights from The Cancer Genome Atlas. Cell Stress and Chaperones, 20(5), 729741. https://doi.org/10.1007/s12192-015-0604-1

Rashmi, R., Santhosh Kumar, T. R., \& Karunagaran, D. (2003). Human colon cancer cells differ in their sensitivity to curcumin-induced apoptosis and heat shock protects them by inhibiting the release of apoptosis-inducing factor and caspases. FEBS Letters. https://doi.org/10.1016/S00145793(03)00099-1

Richter, K., Haslbeck, M., \& Buchner, J. (2010). The Heat Shock Response: Life on the Verge of Death. Molecular Cell. https://doi.org/10.1016/j.molcel.2010.10.006

Riebold, M., Kozany, C., Freiburger, L., Sattler, M., Buchfelder, M., Hausch, F., ... Paez-Pereda, M. (2015). A C-terminal HSP90 inhibitor restores glucocorticoid sensitivity and relieves a mouse allograft model of Cushing disease. Nature Medicine, 21(3), 276-280. https://doi.org/10.1038/nm.3776

Roy, N., Nageshan, R. K., Ranade, S., \& Tatu, U. (2012). Heat shock protein 90 from neglected protozoan parasites. Biochimica et Biophysica Acta - Molecular Cell Research. https://doi.org/10.1016/j.bbamcr.2011.12.003

Sang, J., Acquaviva, J., Friedland, J. C., Smith, D. L., Sequeira, M., Zhang, C., ... Proia, D. A. (2013). Targeted inhibition of the molecular chaperone Hsp90 overcomes ALK inhibitor resistance in non-small cell lung cancer. Cancer Discovery, 3(4), 430-443. https://doi.org/10.1158/21598290.CD-12-0440

Siligardi, G., Zhang, M., \& Prodromou, C. (2018). The Stoichiometric Interaction of the Hsp90-Sgt1-Rar1 Complex by CD and SRCD Spectroscopy. Frontiers in Molecular Biosciences, 4(January), 1-13. 
https://doi.org/10.3389/fmolb.2017.00095

Soudry, E., Stern Shavit, S., Hardy, B., Morgenstern, S., Hadar, T., \& Feinmesser, R. (2017). Heat shock proteins HSP90, HSP70 and GRP78 expression in medullary thyroid carcinoma. Annals of Diagnostic Pathology, 26, 52-56. https://doi.org/10.1016/j.anndiagpath.2016.11.003

Takai, H., Xie, Y., De Lange, T., \& Pavletich, N. P. (2010). Tel2 structure and function in the Hsp90-dependent maturation of mTOR and ATR complexes. Genes and Development. https://doi.org/10.1101/gad.1956410

Verba, K. A., Wang, R. Y. R., Arakawa, A., Liu, Y., Shirouzu, M., Yokoyama, S., \& Agard, D. A. (2016). Atomic structure of Hsp90-Cdc37-Cdk4 reveals that Hsp90 traps and stabilizes an unfolded kinase. Science, 352(6293), 1542-1547. https://doi.org/10.1126/science.aaf5023

Wang, R., Zhang, Y., Kieffer, M., Yu, H., Kepinski, S., \& Estelle, M. (2016). HSP90 regulates temperaturedependent seedling growth in Arabidopsis by stabilizing the auxin co-receptor F-box protein TIR1. Nature Communications, $7, \quad 1-10$. https://doi.org/10.1038/ncomms10269

Wang, X., \& Chen, W. (2012). Gambogic Acid is a Novel Anticancer Agent that Inhibits Cell Proliferation, Angiogenesis and Metastasis. Anti-Cancer Agents in Medicinal Chemistry, 12(8), 994-1000. https://doi.org/10.2174/187152012802650066

Whitesell, L., \& Lin, N. U. (2012). HSP90 as a platform for the assembly of more effective cancer chemotherapy. Biochimica et Biophysica Acta - Molecular Cell Research. https://doi.org/10.1016/j.bbamcr.2011.12.006

Whitesell, L., \& Lindquist, S. L. (2005). HSP90 and the chaperoning of cancer. Nature Reviews Cancer, 5(10), 761-772. https://doi.org/10.1038/nrc1716

Whitley, D., Goldberg, S. P., \& Jordan, W. D. (1999). Heat shock proteins: A review of the molecular chaperones. Journal of Vascular Surgery. https://doi.org/10.1016/S07415214(99)70329-0

Wijaya, F. F., Santosa, L. A., \& Waspadji, S. (2009). Role of heat shock protein in insulin resistance. Majalah Kedokteran Indonesia, 58, 122-127.

Wu, J., Liu, T., Rios, Z., Mei, Q., Lin, X., \& Cao, S. (2017). Heat Shock Proteins and Cancer. Trends in Pharmacological Sciences, 38(3), 226-256. https://doi.org/10.1016/j.tips.2016.11.009

Yin, Z., Henry, E. C., \& Gasiewicz, T. A. (2009). (-)Epigallocatechin-3-gallate is a novel Hsp90 inhibitor. Biochemistry, 48(2), 336-345. https://doi.org/10.1021/bi801637q

Yu, Y., Hamza, A., Zhang, T., Gu, M., Zou, P., Newman, B., ... Sun, D. (2010). Withaferin A targets heat shock protein 90 in pancreatic cancer cells. Biochemical Pharmacology, 79(4), 542-551. https://doi.org/10.1016/j.bcp.2009.09.017
Zhao, H., Moroni, E., Colombo, G., \& Blagg, B. S. J. (2014). Identification of a new scaffold for Hsp90 C-terminal inhibition. ACS Medicinal Chemistry Letters, 5(1), 84-88. https://doi.org/10.1021/ml400404s

Zhao, H., Yan, B., Peterson, L. B., \& Blagg, B. S. J. (2012). 3arylcoumarin derivatives manifest anti-proliferative activity through Hsp90 inhibition. ACS Medicinal Chemistry Letters, 3(4), 327-331. https://doi.org/10.1021/ml300018e 